Research Article

\title{
Distribution and Phytocomponent in the Ethanol Extract of Globba candida Gagnep. (Zingiberaceae) by GC-MS Analysis
}

\author{
Putri Sri Andila *, I Gede Tirta \\ Eka Karya Botanical Garden, Indonesian Institute of Science, Tabanan 82191, Indonesia
}

Article history:

Submission September 2018

Revised September 2018

Accepted September 2018

*Corresponding author:

E-mail: putribot11@gmail.com

\begin{abstract}
Globba is the third largest genera in the Zingiberaceae family, distributed in tropical and sub-tropical regions with the center of biodiversity in Southeast Asia. The study about phytochemical contents Globba is an interesting especially Globba candida Gapnep which have been never reported. The aims of this study were to observe distribution and phytochemical compounds of ethanol extract of $G$. candida Gapnep. found on Bali Island. Hydrodistillation was used to determine the presence of its essential oil and a Gas Chromatography-Mass Spectrometry (GCMS) was used to carry out the phytochemical analysis of the essential oil and ethanol extracts of $G$. candida Gapne. The phytochemical analysis of the rhizomes and leaves ethanol extracts of $G$. candida Gapnep revealed 36 and 8 identified chemical compounds representing $85,82 \%$ and $85,47 \%$ of the total analyzed extracts. However, there was no essential oil constituent found in G. candida Gapnep. The main compounds of the rhizome extract of G. candida Gapnep were levoglucosan $19.07 \%$, allylhydrazone acetaldehyde $5.52 \%$, trans-2,3-epoxybutane $6.30 \%$, butan-3-enoic acid methyl ester 4.36\%, 2-methylcyclopentanone $4.02 \%$, and 2-n-propyl-oxetan $4.00 \%$. While the dominant contents of the leaves extract of $G$. candida Gapnep were pinostrobin chalcone $75.63 \%$.
\end{abstract}

Keywords: Globba candida Gapnep, GC-MS, ethanol extract, chemical compounds, essential oil

\section{Introduction}

Zingiberaceae commonly known as ginger is an aromatic plant, perennial herbs consisting of more than 1,300 species and 52 genera with the tuberous rhizomes and creeping horizontal, distributed from tropical Asia, Africa and America [1]. Among them, the distribution of ginger predominantly was found in tropical Asia with approximately about 1000 species occur in this area. Traditionally, Ginger has been used by people around the world for various purpose as food, traditional medicine, spice, condiment, dye and flavor [2]. Ethnobotany study about medicinal plants in the Buyan-Tamblingan Lake area, Bedugul, Bali revealed that Zingiberaceae was the largest family used by the local people as a traditional medicine, among other as antitoxin of scorpion, treatment for body warmer, anti-inflammatory, rheumatism, skin diseases, fever, weak heart, and painkiller [3]. In Ayurveda (a system of traditional medicine with historical roots in India), ginger was used for many kinds of treatment, as anti-inflammatory decoctions, a cardiac stimulant carminative, rheumatoid arthritis, inflammations, stomatopathy, pharyngopathy, cough, asthma, hiccough, dyspepsia, stomachalgia, obesity, diabetes, cephalalgia, tubercular glands and intermittent fevers [4].

Phytochemical and phytopharmacological studies had also proven that many species in Zingiberaceae family contained various secondary metabolites that had great potential in the pharmaceutical field, such as an anti-inflammatory, antioxidant, antimutagenic, antidiabetic, antibacterial, hepatoprotective, expectorant and anticancer properties [5], antiplatelet, anti-ulcer, anti-convulsive, provides analgesic effects, diarrhea medication, dermatosis disorder, rheumatism, and expec- 
torant [2]. The previous study showed that Alpinia hookeriana Val., Alpinia mutica Roxb., Alpinia nutans Rosc., Alpinia rafflesiana Wall. ex. Bak., Alpinia vitellina Ridl. (Lindl.), Costus discolor Rosc., Costus megalobractea K. Schum., Costus spiralis Rosc., Costus villosissimus Jacq contained some phenolic compounds which exhibited positive antioxidant activity [6]. In the other hand, Verma et al. [7] reported that the essential oil of Zingiber montanum contained DMPBD, terpinen4-ol and sabinene as dominant compound and these constituents could be used as a potential source for several pharmaceutical products. The biological activity assay also performed that this essential oil had strong antibacterial and antifungal activity against several human pathogen bacterial and fungal.

Globba is the third largest genera in the Zingiberaceae family, consisting of more than 100 species. The Globba genus is widely distributed in tropical and sub-tropical regions, including Asia (India, China) with the highest diversity center in the Southeast Asia region (Thailand, Myanmar, Malaysia, and Indonesia) [8]. It has been a long time since phytochemical studies of Globba have been an interesting object to be explored by scientists. The presence of major chemical contents of Globba schomburgkii Hook. F. and Globba ophioglossa Wight had been detected by Raj et al. [9] among others cyperene $3.1 \%$ (Gs), $0.9 \%$ (Go), b-caryophyllene $31.7 \%$ (Gs), 1.0\% (Go), aromadendrene 5.5\% (Gs), a-humulene 5.3\% (Gs), $0.7 \%$ (Go), caryophyllene oxide $10.3 \%$ (Gs), 21.8\% (Go), (E)-nerolidol 5.7\% (Go), humulene epoxide* $5.9 \%$ (Go), zerumbone $22.0 \%$ (Go), 13,14,15,16-tetranor labd-8(17)-en-12-al 6.6\% (Gs), 2.2\% (Go), hexadecanoic acid 7.6\% (Gs) $19.6 \%$ (Go). But in reality, there is still a lot of information about chemical compounds records in Globba genera that have not been revealed. One of them was G. candida Gapnep, a native species in Indo-china region [10]. Three accessions of $G$. candida Gapnep were found by researchers from Eka Karya Botanical Garden during explorations in the natural habitat (not planted) in Bali and Sumbawa, and these new distributions are still unclear records. The aims of this present study were to investigate the real distribution of G. candida Gapnep by comparing literature reviewed and its exploration histories. This study also to observe phytochemical composition in the ethanol extract of G. candida Gagnep from Bali Island.

\section{Material and Methods Plant material}

G. candida Gapnep was collected from the border area between natural forests and community gardens at Pangkung Jangu Village, a traditional village in Mendoyo Sub-district, Jembrana Regency, Bali Province, Indonesia on March 2007 and planted at Eka Karya Botanical Garden on February 2009. In the natural habitat, this plant grows in the open area with altitude 150 masl. In Eka Karya Botanical garden, this plant was planted at USADA block area, with temperature ranging between $18-20^{\circ} \mathrm{C}, 70-90 \%$ humidity and altitude of 1,250 - 1,450 masl [11]. A voucher of herbarium specimen with number Put 54 was identified by a taxonomist of Eka Karya Bali Botanical Garden, I B K Arinasa, M.Si. and deposited in the Tabanan Hortus Botanicus Baliense (THBB).

\section{Isolation of essential oil}

The essential oil content was observed and isolated from the fresh material of the aerial part of G. candida Gapnep. Respectively, $100 \mathrm{~g}$ fresh sample was harvested on March 2016 and extracted by hydrodistillation for five hours using a Pudak Scientific apparatus. The essential oil was separated from hydrosol by using a Duran Schott separator [12].

\section{Extraction process}

Fresh material of the rhizome and leaves of $G$. candida Gapnep were harvested on March 2016 and chopped in small size and dried several days at room temperature and avoided the sun irradiance until the materials were completely dry. One hundred grams of each dried materials of G. candida Gapnep were extracted with ethanol by the maceration method and the extract suspension was filtered by filter paper [13]. These extract suspensions were analyzed with GC-MS to determine the chemical contents.

\section{GC-MS analysis}

The phytochemical composition of the aerial part essential oil and the ethanol extracts of rizomes and leaves of G. candida Gapnep were analyzed by GC-MS equipment model Shimadzu GC-MS - QP2010 with Rtx 5 ms and capillary 


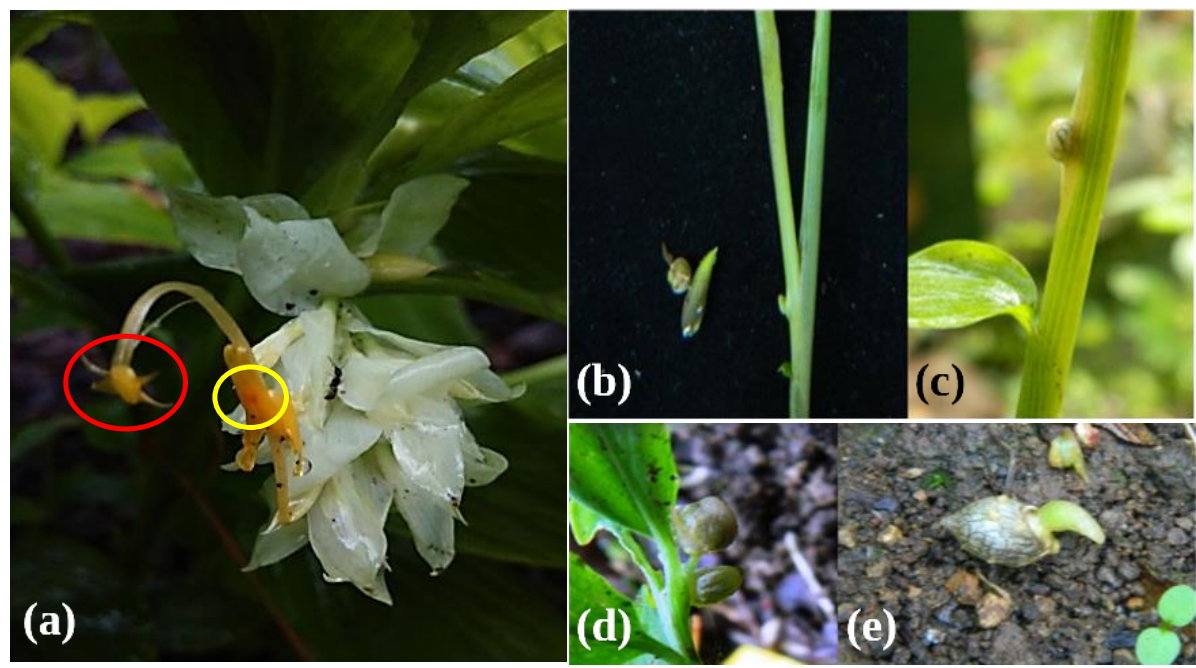

Figure 1. The inflorescence and the bulbil of G. candida Gapnep: terminal inflorescence with open flower and large white bractea; anther with 4 triangular appendages (red line) and red spot in the center of labellum (yellow line) (a), bulbil between leaf midribs (b and c), bulbils at the position of the last flower in cincinni (d), and the buds emerge from the bulbil (e).

column $60.0 \mathrm{~m} \times 25 \mathrm{~mm}$ with $0.25 \mu \mathrm{m}$ thickness. The carrier gas was helium UHP with the condition of GC setting and it based on similar method from another research [12].

\section{Data analysis}

The chemical compounds were identified by mass spectra fragmentation patterns and their identity was approved by comparing their retention time indices and their spectral data with those from computer library WILEY7.LIB and open published literature.

\section{Results and Discussion \\ Distribution of G. candida Gapnep}

G. candida Gapnep was reported as an accepted name among of Globba Species with original publication detail was published in Bull. Soc. Bot. France 54: 112. 1907 and this name were approved by World Checklist of Monocotyledons Database in ACCESS: 1-54382 [10]. The first reported about the distribution of this species was native in Indo-china, especially in Cambodia [10, 14]. But the database the Global Biodiversity Information Facility (GBIF) published that the $G$. candida Gapnep occurred in Cambodia, Thailand, Indonesia and Lao People's Democratic Republic (Laos) [15]. Base on exploration records which had been conducted by researchers from Eka Karya Bali Botanical Garden, the occurrence of $G$. candida Gapnep in Indonesia had been reported three times, specifically in Bali and Sumbawa. On March 2007, an accession of G. candida Gapnep was found in an open area, altitude 150 masl, in Pangkung Jangu Village, Mendoyo Sub-district, Jembrana Regency, Bali Province. On July 2014, this species was found flowering in the slope of Batukaru Mountain, altitude about 700 masl, near Batu Asri Temple, Pujungan Village, Pupuan SubDistrict, Tabanan Regency, Bali. On Mei 2015, an accession of $G$. candida Gapnep was also found in Punik Natural Forest, Batu Dulang Village, Batulanteh Regency, Sumbawa Island, West Nusa Tenggara (S 08³5'.866”'E117¹4'501”; altitude 965 masl) [16]. There is no publication in scientific journal reporting on G. candida Gapnep new distribution in Indonesia.

To observe the possibility of G. candida Gapnep spreading through cultural and religious factors, deeply literature searching was conducted. Based on reports of Siregar et al. [17] and Adiputra [18] about the ceremonial plant diversity in Bali Hindu Community, there was no information that mentions the use of G. candida Gapnep in Balinese ceremonial requirements. While the use of G. candida Gapnep in traditional medicinal plants Balinese community was also not found in the book of Lontar Husada [19].

An In-depth interview with respondents of local community was used to collect data of localnknowledge about the local name and ethnobotanical function of plants collected around the Punik 
Table 1. The Phytochemical compounds of ethanol extract of the rhizomes G. candida Gapnep

\begin{tabular}{|c|c|c|c|c|}
\hline No. & Chemical Compound & $\begin{array}{c}\text { Mol. } \\
\text { Formula }\end{array}$ & $\begin{array}{c}\text { R. } \\
\text { Time }\end{array}$ & $\begin{array}{c}\text { Rel. Conc. } \\
\%\end{array}$ \\
\hline 1. & $\begin{array}{l}\text { Butan-3-enoic acid Methyl } \\
\text { Ester }\end{array}$ & - & 3.42 & 4.36 \\
\hline 2. & Diacetyl & $\mathrm{C}_{4} \mathrm{H}_{6} \mathrm{O}_{2}$ & 4.06 & 1.03 \\
\hline 3. & Acetic Acid & $\mathrm{C}_{2} \mathrm{H}_{4} \mathrm{O}_{2}$ & 4.83 & 3.93 \\
\hline 4. & Trans-2,3-Epoxybutane & $\mathrm{C}_{4} \mathrm{H}_{8} \mathrm{O}$ & 5.39 & 6.30 \\
\hline 5. & Methyl Pyruvate & $\mathrm{C}_{4} \mathrm{H}_{6} \mathrm{O}_{3}$ & 8.18 & 3.26 \\
\hline 6. & Dioxadiene & $\mathrm{C}_{4} \mathrm{H}_{8} \mathrm{O}_{2}$ & 8.46 & 0.95 \\
\hline 7. & Allyl butyrate & $\mathrm{C}_{7} \mathrm{H}_{12} \mathrm{O}_{2}$ & 9.02 & 0.59 \\
\hline 8. & Methallylacetone & $\mathrm{C}_{7} \mathrm{H}_{12} \mathrm{O}$ & 9.89 & 3.10 \\
\hline 9. & $\begin{array}{l}\text { 3,4-Dimethyl-4-penten-1yn- } \\
\text { 3-ol }\end{array}$ & $\mathrm{C}_{7} \mathrm{H}_{12} \mathrm{O}$ & 10.83 & 0.60 \\
\hline 10. & 2-Methylcyclopentanone & $\mathrm{C}_{6} \mathrm{H}_{10} \mathrm{O}$ & 11.36 & 4.02 \\
\hline 11. & Pinacolone & $\mathrm{C}_{6} \mathrm{H}_{12} \mathrm{O}$ & 11.59 & 0.99 \\
\hline 12. & 3-Methyl-2-cyclopentenone & $\mathrm{C}_{6} \mathrm{H}_{8} \mathrm{O}$ & 11.90 & 1.14 \\
\hline 13. & Methylcyclopentenolone & $\mathrm{C}_{6} \mathrm{H}_{8} \mathrm{O} 2$ & 12.99 & 1.97 \\
\hline 14. & Ethyloctynol & $\mathrm{C}_{10} \mathrm{H}_{18} \mathrm{O}$ & 13.21 & 0.70 \\
\hline 15. & 1-Acetylcyclohexene & $\mathrm{C}_{8} \mathrm{H}_{12} \mathrm{O}$ & 13.61 & 1.77 \\
\hline 16. & m- cresol & $\mathrm{C}_{7} \mathrm{H}_{8} \mathrm{O}$ & 13.74 & 1.21 \\
\hline 17. & 2-Propyloxetane & $\mathrm{C}_{6} \mathrm{H}_{12} \mathrm{O}$ & 14.06 & 4.00 \\
\hline 18. & $\begin{array}{l}\text { 2H-Pyran-3(4H)-one, } \\
\text { dihydro-6-methyl- }\end{array}$ & $\mathrm{C}_{6} \mathrm{H}_{10} \mathrm{O}_{2}$ & 14.42 & 1.01 \\
\hline 19. & $\begin{array}{l}\text { 2H-Pyran-3(4H)-one, } \\
\text { dihydro- }\end{array}$ & $\mathrm{C}_{5} \mathrm{H}_{8} \mathrm{O}_{2}$ & 14.64 & 1.26 \\
\hline 20. & Caprylene & $\mathrm{C}_{8} \mathrm{H}_{16}$ & 15.01 & 0.70 \\
\hline 21. & $\begin{array}{l}\text { Allylhydrazone acetalde- } \\
\text { hyde }\end{array}$ & $\mathrm{C}_{5} \mathrm{H}_{10} \mathrm{~N}_{2}$ & 15.35 & 5.52 \\
\hline 22. & 4-Ethylguaiacol & $\mathrm{C}_{9} \mathrm{H}_{12} \mathrm{O}_{2}$ & 16.09 & 1.37 \\
\hline 23. & Beta.Damascone & $\mathrm{C}_{13} \mathrm{H}_{20} \mathrm{O}$ & 16.38 & 0.84 \\
\hline 24. & Longipinane, Trans & $\mathrm{C}_{15} \mathrm{H}_{26}$ & 16.51 & 0.57 \\
\hline 25. & 1,2,4-Cyclopentanetriol & $\mathrm{C}_{5} \mathrm{H}_{10} \mathrm{O}_{3}$ & 16.63 & 0.60 \\
\hline 26. & $\begin{array}{l}\text { D-Glucose, 4-O-(3-acetyl-1- } \\
\text { (trimethylsilyl)-1H-indolyl)- } \\
\text { 2,3,5,6-tetrakis-O-(trim) }\end{array}$ & - & 16.99 & 0.81 \\
\hline 27. & Farnesol & $\mathrm{C}_{15} \mathrm{H}_{26} \mathrm{O}$ & 17.36 & 2.55 \\
\hline 28. & Cycloisosativene & $\mathrm{C}_{15} \mathrm{H}_{24}$ & 17.87 & 0.65 \\
\hline 29. & Levoglucosan & $\mathrm{C}_{6} \mathrm{H}_{10} \mathrm{O}_{5}$ & 18.80 & 19.07 \\
\hline 30. & $\begin{array}{l}\text { (5-alpha)-Cholest-7-EN-3- } \\
\text { one }\end{array}$ & $\mathrm{C}_{27} \mathrm{H}_{44} \mathrm{O}$ & 20.39 & 1.86 \\
\hline 31. & $\begin{array}{l}\text { Cyclohexene, 4-(4 Ethylcy- } \\
\text { clohrxyl)-1-Pentyl }\end{array}$ & $\mathrm{C}_{19} \mathrm{H}_{34}$ & 22.18 & 0.75 \\
\hline 32. & Lanost-7-en-3-one & $\mathrm{C}_{30} \mathrm{H}_{50} \mathrm{O}$ & 23.13 & 3.27 \\
\hline 33. & $\begin{array}{l}\text { 4-2',2'-Dimethyl 6'methyli- } \\
\text { den-1'cyclohexyliden)-3- } \\
\text { methyl-2-butanone }\end{array}$ & $\mathrm{C}_{14} \mathrm{H}_{22} \mathrm{O}$ & 23.75 & 2.72 \\
\hline 34. & 3beta-Bromocholest-5-ene & $\mathrm{C}_{27} \mathrm{H}_{45} \mathrm{Br}$ & 24.04 & 0.56 \\
\hline 35. & Olean-12-en-3-one & $\mathrm{C}_{30} \mathrm{H}_{48} \mathrm{O}$ & 24.67 & 1.21 \\
\hline 36. & $\begin{array}{l}\text { Naphthalene, ar, ar' ar"me- } \\
\text { thylidynetris (Decahydro- }\end{array}$ & 50 & 26.74 & 0.58 \\
\hline & Total & & & 85.82 \\
\hline
\end{tabular}

Note:Mol Formula: Molecular Formula; R. Time: Retention Time; Rel. Conc.: Relative concentration

Natural Forest, Batu Dulang Village, Batulanteh Regency, Sumbawa Island, West Nusa Tenggara, during exploration by the researchers of Bali Botanic Garden on Mei 2015, and the results showed that there were no records of the local name and ethnobotanical function of $G$. candida Gapnep [16]. So, it is still a big question whether the distribution of G. candida Gapnep found in Bali and Sumbawa is natural distribution or dispersed due
Table 2. The Phytochemical compounds of ethanol extract of the rhizomes G. candida Gapnep

\begin{tabular}{ccccc}
\hline No. & Chemical Compound & $\begin{array}{c}\text { Mol. } \\
\text { Formula }\end{array}$ & $\begin{array}{c}\text { R. } \\
\text { Time }\end{array}$ & $\begin{array}{c}\text { Rel. } \\
\text { Conc. \% }\end{array}$ \\
\hline 1. & 2-Methylfluorene & $\mathrm{C}_{14} \mathrm{H}_{12}$ & 19.59 & 0.69 \\
2. & Palmatic Acid & $\mathrm{C}_{16} \mathrm{H}_{32} \mathrm{O}_{2}$ & 20.89 & 1.70 \\
3. & Alpha-ionone & $\mathrm{C}_{13} \mathrm{H}_{20} \mathrm{O}$ & 21.84 & 0.70 \\
4. & $\begin{array}{c}\text { Ambrettolide } \\
\mathrm{C}_{16} \mathrm{H}_{28} \mathrm{O}_{2}\end{array}$ & 22.68 & 0.62 \\
1-(1-(Hydroxy-Phenyl- & & & \\
5. & Methyl)-Cyclopropyl)-2- & - & 22.92 & 2.40 \\
6. & Phenyl-Ethano & & & \\
7. & Benzenepentanal & $\mathrm{C}_{11} \mathrm{H}_{14} \mathrm{O}$ & 23.57 & 2.08 \\
8. Dibenzylacetone & $\mathrm{C}_{17} \mathrm{H}_{18} \mathrm{O}$ & 24.29 & 1.65 \\
\hline \multicolumn{7}{c}{ Pinostrobin chalcone } & $\mathrm{C}_{16} \mathrm{H}_{14} \mathrm{O}_{4}$ & 25.44 & 75.63 \\
\hline
\end{tabular}

Note: Mol Formula : Molecular Formula; R. Time: Retention Time; Rel. Conc.: Relative Concentration

to other human activities.

\section{Description of G. candida Gapnep}

G. candida Gapnep was a small perennial herb from $50-70 \mathrm{~cm}$ tall (Figure 1). Rhizomes were tuberculous, $20-25 \mathrm{~mm}$ length, $3-4 \mathrm{~mm}$ in diameter, white with the white color internally. Leafy shoots were densely clumped, 5 - 7 leaves in a stem, stems bright green, sometimes red green in the lower stem. Leaves were glabrous and soft, only midvein of the ventral surface pubescent, lamina $8-17 \times 3.5-5.5 \mathrm{~cm}$ elliptic bright green adaxially, pale green and hairy abaxially, margin entire, base cuneate, apex acuminate with long acumen. Size of petiole was $3-5 \mathrm{~mm}$, and fluffy smooth, green. Ligule was small, $2-3 \mathrm{~mm}$ in length, and hirsutulous. Inflorescence was terminal on leafy shoots with striking feature a large and white bractea. The color of flowers was orange and had a red spot in the center labellum. Anther consisted of 4 appendages; appendages triangular. Bulbils was at the position of the last flower in cincinni and between leaf midribs, many roots and shoots but there was only one who was developed into bamboo-like shoot. Fruit and seeds were unknown.

\section{The Essential oil contents of G. candida Gapnep}

This present study was the first report about the essential oil observation in G. candida Gapnep. After five hours extraction by hydrodistillation, the result showed that there was no essential oil content found in the aerial part of G. candida Gapnep. The presence of essential oils in Globba spp. had been reported in several studies. Meno and and Dan [20] found the essential oil contents 


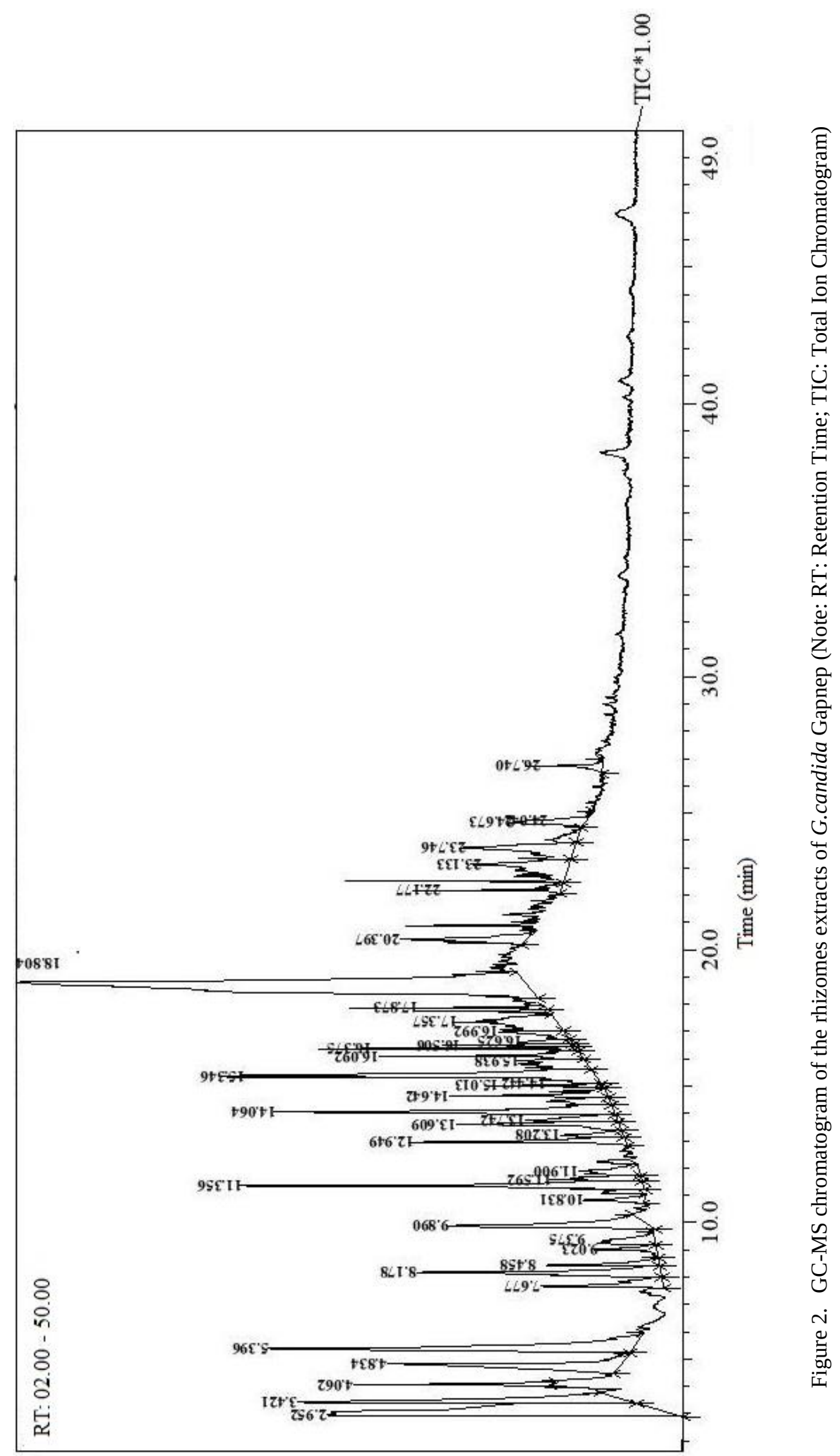

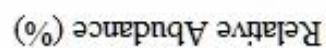




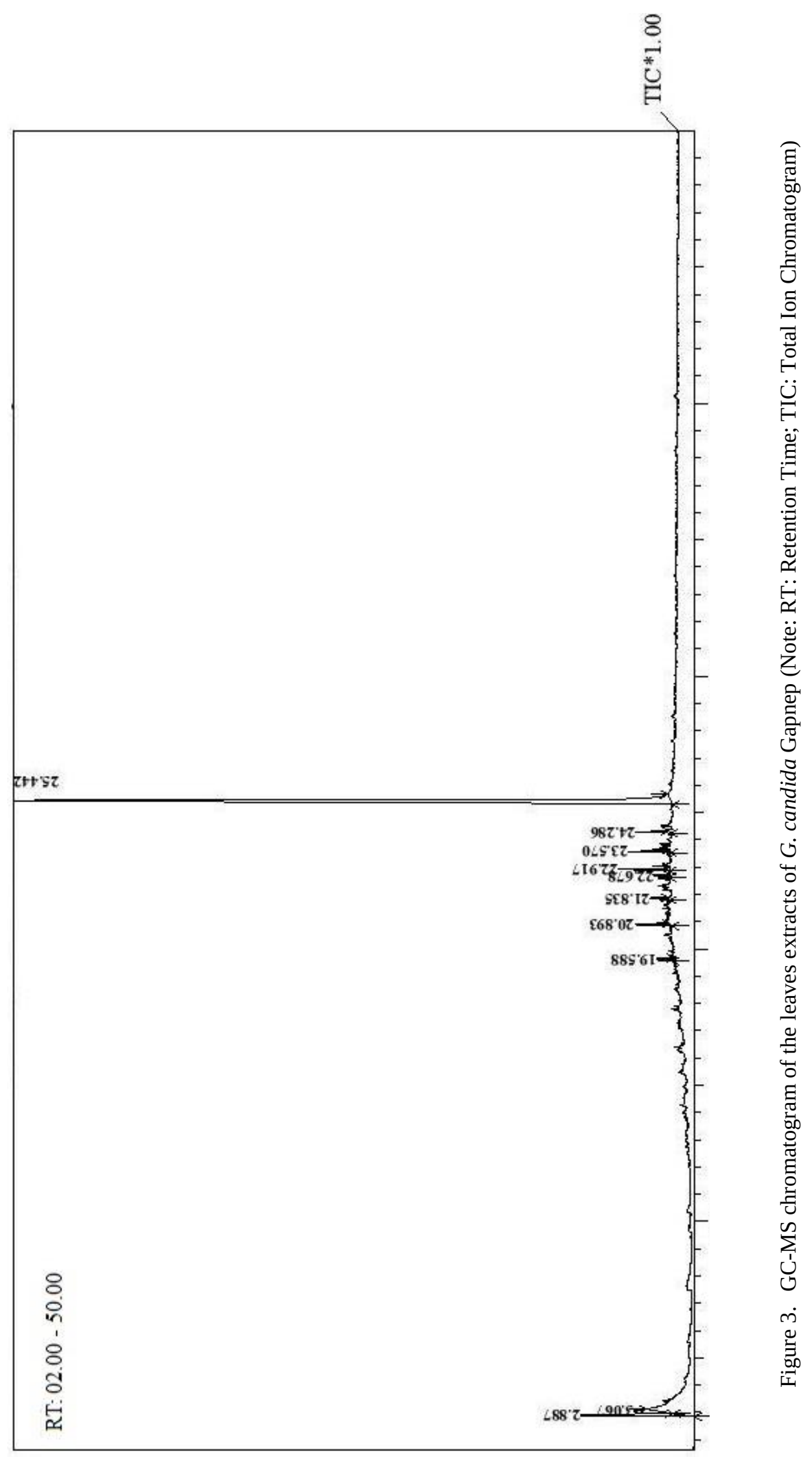

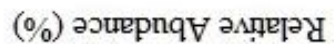


in three species of Globba with various concentration, namely G. marantina $(0.007 \%(\mathrm{~V} / \mathrm{W}))$, Globba ophioglossa (0.009\% (V/W)), and Globba cernua $(0.006 \%(\mathrm{~V} / \mathrm{W}))$. Consecutively, the essential oil of Globba marantina, G. ophioglossa, and G. cernua comprised of 13, 16, and 10 identified chemical constituents accounting 74.8\%; $16 \%$; and $10 \%$ of the total oils. The main compounds of $G$. marantina were b-caryophyllene 19.3\%, a-humu-lene 14.2\%, (Z) neroli-dol 7.5\%, isoborneol $7.3 \%$, and b-bisabolene $7.2 \%$. While the major constituents of $G$. ophioglossa were bcaryophyllene $20.1 \%$, (Z,Z)-farnesol 9.8\%, cedrol $7.3 \%$, (e)-anethole $6.3 \%$, neryl acetate $6.8 \%$ and the dominant compounds of $G$. cernua were b-caryophyllene $24.2 \%$, Z)-nerolidol $7.8 \%$, caryophyllene oxide 7.7\%, (Z,Z)-farnesol 9.8\%, (E)-anethole $6.3 \%$ [20].

The essential oils content of $G$. schomburgkii and G. ophioglossa were also detected by Raj et al [9] in the low concentration $0.01 \%(\mathrm{v} / \mathrm{w})$. This report showed that $G$. schomburgkii oil contained 22 identified constituents, comprising of $95.2 \%$ of the total oil composition with the major compounds of this species were b-caryophyllene (31.7\%), caryophyllene oxide (10.3\%), hexadecanoic acid (7.6\%) and a labdane-type diterpene 13,14,15,16-tetranor labd-8(17)- en-12-al (6.6\%). In the other hand, the essential oil of G. ophioglossa consisted of 16 identified constituents representing $88.3 \%$ of the analyzed oil with zerumbone $22.0 \%$, caryophyllene oxide $21.8 \%$, and hexadecanoic acid $19,6 \%$ as major constituents. Kumar et al. [21] also found the essential oil contents in rhizome of Globba sessiliflora Sims with comprising of 35 determined contents (representing $98.1 \%$ of the oil) and exhibiting $\beta$-eudesmol (27.6\%), (E)- $\beta$-caryophyllene (24.3\%), $\alpha$-humulene (3.0\%), (6E)-nerolidol (4.1\%), caryophyllene oxide $(9.7 \%)$, $\gamma$-eudesmol (6.4\%) and $\tau$-muurolol $(8.3 \%)$ as major compound.

\section{The Phytochemical compounds of ethanol ex- tract of the rhizome and leaves of G. candida Gapnep}

The rhizome and leaves extract of $G$. candida Gapnep consisted of 36 and 8 identified chemical contents, representing $85.82 \%$ and $85.47 \%$ of the total analyzed extracts. The complete results of the phytochemical compounds can be seen in Table 1 and Table 2 and their GC-MS chromatograms in
Figure 1 and Figure 2. Among of them, the major compounds of the rhizome extract of $G$. candida Gapnep were levoglucosan $19.07 \%$, allylhydrazone acetaldehyde $5.52 \%$, trans-2,3-epoxybutane $6.30 \%$, butan-3-enoic acid methyl ester $4.36 \%$, 2Methylcyclopentanone $4.02 \%$, and 2-N-PropylOxetan $4.00 \%$. While the dominant contents of the leaves extract of $G$. candida Gapnep were pinostrobin chalcone $75.63 \%$.

As far as the author's investigation, there is no previous study pertaining to the chemical contents in G. candida Gapnep has been carried out. However, prior phytochemical studies on the genus Globba have revealed several contents as main compounds, among other the presence sesquiterpene and diarylheptanoid in G. malaccensis Ridl (A synonym for G. variabilis subsp. Variabilis) [22]; two new chemical compounds of lipids, three new labdane-type diterpenes and two new steroids from the rhizomes of G. reflexa [23]; triterpene and steroids from G. racemosa Sm; phenolic compound, steroid, labdane, diterpene and benzofuran from G. pendula Roxb. [24]; heptadecane, pinocarvone, l-linalool, alloaromadendrene, $\beta$-caryophyllene, $\alpha$ - humulene, terpineol, lavandulol, 2,6-dimethyl-1,5,7-octatrien-3-ol in methanol crude extract from G. marantina [25] and steroids, alkaloids, flavonoids, cardiac glycosides, saponins, tannins, terpenoids, phlobatinins, fatty acids, coumarins and phenols compounds from ethanolic tuber extract of $G$. bulbifera [26].

\section{Conclusion}

G. candida Gapnep is one species in the genus Globba that has not been widely studied, especially in the analysis of chemical content and its potential. The phytochemical constituents of rhizomes and leaves extract of this species was done for the first time. This present investigation will be helpful for further research of G. candida Gapnep both related to chemotaxonomic or for phytochemical analysis

\section{Acknowledgment}

The authors would like to say thank Essential Oil Research Group at Eka Karya Botanical Garden - Bali, Indonesian Institute of Science for funding this research (DIPA-2016). We would also like to say thank to Mr. Ida Bagus Ketut Arinasa and Tri Warseno, S.Si. for their contributions during conducting of this study. 


\section{References}

1. Tamokou JDD, Mbaveng AT, Kuete V (2017) Antimicrobial activities of African medicinal spices and vegetables. In: Kuete V (Ed.) Medicinal spices and vegetables from Africa. London, UK, Academic Press. pp 207 - 237. doi: 10.1016/b978-0-12809286-6.00008-X.

2. Ujang Z, Nordin NI, Subramaniam T (2015) Ginger species and their traditional uses in modern applications. Journal of Industrial Technology 23 (1): 59 - 70.

3. Oktavia GAE, Drama IDP, Sujarwo W (2017) Ethnobotanical study of medicinal plants in the area around Buyan-Tamblingan. Buletin Kebun Raya 20 (1): 1 - 16.

4. Kumar KMP, Asish GR, Sabu M, Balachandra I (2013) Significance of gingers (Zingiberaceae) in Indian System of Medicine - Ayurveda: An overview. Ancient Science of Life 32 (4): 253 - 261. doi: 10.4103/0257-7941.131989.

5. Barbosa GB, Jayasinghe NS, Natera SHA et al. (2017) From common to rare Zingiberaceae plants - A metabolomics study using GC-MS. Phytochemistry 140: 141 - 150. doi 10.1016/j.phytochem.2017.05.002.

6. Asif M (2015) Chemistry and antioxidant activity of plants containing some phenolic compounds. Chemistry International 1 (1): $35-52$

7. Verma RS, Joshi N, Padalia RC et al. (2018) Chemical composition and antibacterial, antifungal, allelopathic and acetylcholinesterase inhibitory activities of Cassumunar-ginger. Journa of Science of Food and Agriculture 98 (1): 321 - 327. doi: 10.1002/jsfa.8474

8. Williams KJ, Kress WJ, Monas PS (2004) The Phylogeny, evolution, and classification of the genus Globba and tribe Globbeae (Zingiberaceae): Appendages do matter. American Journal of Botany 91(1): 100 - 114. doi: 10.3732/ajb.91.1.100.

9. Raj G, George V, Dan M, Sethuraman MG (2010) Essential oil composition of Globba schomburgkii Hook. f. and Globba ophioglossa Wight, Journal of Essential Oil Research 22 (3): 220 222. doi: 10.1080/10412905.2010.9700307.

10. The International Plant Name Index (2018) Zingiberaceae Globba candida Gagnep. http://www.ipni.org/ipni/idPlantNameSearch.do?id=872531-1. Accessed date: Agustus 2018.

11. Peneng IN, Andila PS (2017) Keanekaragaman piper liar di hutan sekunder Kebun Raya Eka Karya Bali, Desa Candikuning, Baturiti, Tabanan. In the Proceedinng of Seminar Nasional Biodiversitas: 4 November 2016: Solo. Edited by Septiasari A, Astuti A, Berlian IN et al. pp $173-177$.

12. Andila PS, Wibawa IPAH, Tirta IG, Fardenan D (2018) First report from Indonesia, phytochemical composition of essential oils from leaves and fruits of Zanthoxylum avicennae (Lam.) DC. Journal of Biological Researches Berkala Penelitian Hayati 23 (2): 101 - 106. doi: 10.23869/bphjbr.23.2.20189.

13. Azwanida NN (2015) A Review on the extraction methods use in medicinal plants, principle, strength and limitation. Medicinal
Aromatic Plants Journal 4 (3): 1 - 6. doi: 10.4172/21670412.1000196 .

14. KewScience (2018) Plants of the world online: Globba candida Gapnep. Royal Botanic Garden. http://powo.science.kew.org/ taxon/urn:Isid:ipni.org:names:872531-1. Accessed date: August 2018.

15. The Global Biodiversity Information Facility (2018) Globba candida Gagnep. https://www.gbif.org/species/2757854/metrics. Accessed date: August 2018.

16. Tirta IG, Arinasa IDK, Wibawa IPAG et al. (2015) The exploration of Plants producing essential oil In Sumbawa Island, West Nusa Tenggara. The exploration report. Plant Conservation Centre, “Eka Karya” Botanic Garden. (Not Published).

17. Siregar M, Lugrayasa IN, Mudiana D, Siregar HM (2003) Koleksi tanaman upacara adat Kebun Raya "Eka Karya” Bali. Bali, UPT Balai Konservasi Tumbuhan Kebun Raya "Eka Karya” Bali.

18. Adiputra N (2011) Tanaman Obat, tanaman upacara dan pelestarian lingkungan. Jurnal Bumi Lestati 11 (2): 346 - 354.

19. Tengah IGP, Arka IW, Sritamin NM et al. (1995) Laporan Penelitian: Studi tentang inventarisasi, determinasi dan cara penggunaan tanaman obat “Lontar Usada” di Bali. Jakarta, Pusat Penelitian dan Pengembangan Farmasi Badan Penelitian dan Pengembangan Kesehatan - Departemen Kesehatan Republik Indonesia.

20. Menon AN, Dan M (2009) Chemical composition of essential oils of Globba species from South India. Journal of Essential Oil Research 21 (1): 59 - 60. doi: 10.1080/10412905.2009.970 0110 .

21. Kumar R, Prakash O, Pant AK et al. (2017) Chemical composition and anti-inflamatory, anti-nociceptive and antipyretic activity of rhizome essential oil of Globba sessiliflora Sims. collected from Garhwal region of Uttarakhand. Journal of Herbal Drugs 8 (1): 59 - 69. doi: 10.18869/JHD.2017.59.

22. Muangsin N, Ngamrojnavanich N, Onanong S et al. (2004) Crystal structure of curcumenol: Evidence of asymmetric $\mathrm{O}$ H...O (bridged) hydrogen-bonded closed dimer. Journal of Structural Chemistry 45 (2): 293 - 297. doi: 10.1023/B:JORY. 0000048881.57572.ef.

23. Maulidiani SK, Paetz C, Abas FJ, Laj NH (2009) Naturally occurring labdane diterpene and benzofuran from Globba pendula. Natural Product Communications 4 (8): 1031 - 1036.

24. Manokam N, Nuntawong N (2014) Chemical constituents from the rhizomes of Globba reflexa Craib. Biochemical Systematics and Ecology 57: 395 - 398. doi: 10.1016/j.bse.2014.09.021.

25. Nayak S, Jena AK, Mittal DK, Joshi D (2014) GC - MS analysis of phytoconstituents of some wild Zingiberaceae plants methanolic rhizome extracts. Research in Plant Sciences 2 (1): 1 - 5. doi: 10.12691/plant-2-1-1.

26. Narasinga Rao V and Kaladhar DSVGK (2014) Phytochemical and biochemical studies of medicinal plant Globba bulbifera. 
International Journal of Phytotherapy 4 (1): 50 - 53. 
This page is intentionally left blank. 